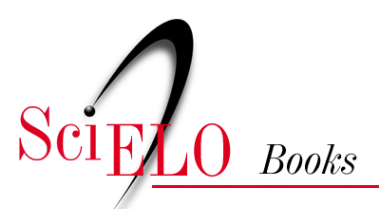

\title{
Histórias do Dr. Henrique Lenzi (17 de setembro de 1999)
}

\author{
Virgínia Schall
}

\section{SciELO Books / SciELO Livros / SciELO Libros}

SCHALL, V. Histórias do Dr. Henrique Lenzi (17 de setembro de 1999). In: Contos de Fatos: histórias de Manguinhos [online]. Rio de Janeiro: Editora FIOCRUZ, 2001, pp. 171-193. ISBN: 978-

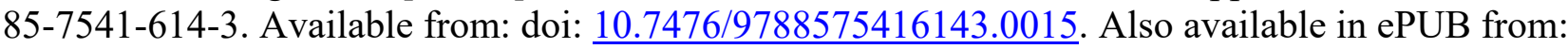
http://books.scielo.org/id/hdq6f/epub/schall-9788575416143.epub.

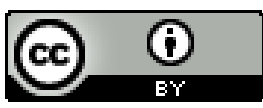

All the contents of this work, except where otherwise noted, is licensed under a Creative Commons Attribution $\underline{4.0 \text { International license. }}$

Todo o conteúdo deste trabalho, exceto quando houver ressalva, é publicado sob a licença $\underline{\text { Creative Commons }}$ Atribição 4.0. 


\title{
Histórias do Dr. Henrique Lenzi
} (17 de setembro de 1999) ${ }^{44}$

\author{
Where did the parasites learn their immunology? \\ Not from Roit, noteven the latest edition; nor \\ from Immamology Today; and notevenfrom \\ attending useful symposia. Rather, they hare \\ learned their craft in the tough classroom of \\ Natural Selection.
}

R. J. Terry ${ }^{45}$

$\mathrm{E}$

ra uma manhã de setembro e o Lenzi, com sua maneira sempre gentil de tratar a todos, disse que estaria orientando um trabalho de uma estudante de pós-graduação, mas poderia fazer uma pausa para me receber. Fui para o Departamento de Patologia, chefiado por ele, no Pavilhão Gomes de Farias, um pequeno prédio atrás do Pavilhão do Relógio, onde ele ocupa o primeiro andar. São diversas salas, algumas apertadas, que abrigam modernos computadores e o excepcional microscópio confocal, onde circulam pesquisadores e estudantes: um autêntico ambiente científico. Quando cheguei, Lenzi recebia um grupo de pesquisadores de uma outra instituição

\footnotetext{
44 Texto reescrito, em parte, pelo entrevistado.

${ }^{45}$ Epígrafe incluída por Dr. Lenzi em um artigo de sua autoria, publicado nas Memórias do Instituto Oswaldo Cruz, 79:13-18, 1984.
} 
e, durante nossa conversa, foi sempre solicitado por telefonemas e pessoas, uma amostra de sua agenda diária, que exige uma extensão da jornada de oito horas - é comum encontrá-lo ali tarde da noite.

Já havíamos combinado o assunto, no refeitório de Biomanguinhos, no dia anterior. Eu havia falado um pouco sobre a intenção do livro e ele me adiantara a história que iria focalizar, uma descoberta sua, feita em colaboração com a Dra. Deane. Para mim, foi uma oportunidade dupla: conhecer o trabalho do Lenzi e fazer presente no livro o trabalho da Dra. Deane, com quem eu chegara a combinar uma entrevista que acabou não acontecendo. A nossa conversa foi muito além dessa história, enriquecida pelo entusiasmo com que Lenzi descreve os fenômenos e os livros maravilhosos que está sempre a descobrir.

Depois que lhe expliquei o meu interesse nos acasos da ciência, contoume sobre a descoberta do pesquisador australiano, M. A.Vadas, que relatou como descobriu, de forma acidental, uma técnica, historicamente importante, de purificação de eosinófilos. Vadas fazia o pós-doutorado no laboratório do Dr. John David, no mesmo local onde mais tarde Lenzi veio a fazer o seu (Laboratório de Imunoparasitologia do Departamento de Medicina da Escola Médica da Universidade de Harvard). Vadas estava tentando purificar eosinófilos humanos com solução de metrizamida, e não obtinha sucesso. Repetia e repetia os experimentos, e não conseguia resultados adequados. Até que, um belo dia, houve um erro numa das soluções, a qual ficou hipertônica, quando deveria ser isotônica. Por esse erro acidental de laboratório, os eosinófilos passaram a ser obtidos com alto índice de purificação. A partir daí, derivou-se uma importante linha de pesquisa no laboratório do Dr.J. David sobre a função e regulação do eosinófilo, principalmente em doenças parasitárias. Este exemplo mostra que muitas descobertas em laboratório decorrem de tentativa e erro, e não podem ser previstas nos objetivos e/ou no material e métodos de um projeto. Segundo Lenzi, a melhor pesquisa é aquela que ocorre no caminhar, no experenciar, sem qualquer resultado previsto! Hoje, as agências de pesquisa 
exigem que os pesquisadores tenham a capacidade de prever o futuro! É a anticiência! As agências financiadoras preferem promover pesquisas com resultados previsíveis e esperados! É a aplicação exagerada do método galileano ou limitado-pela-hipótese! Mas a pesquisa biológica pós-genômica, decorrente do uso de metodologias mais complexas e menos lineares como - microar ray chip ou $c D N A$ chip, deslocará o tipo de pesquisa dependente de hipótese para uma pesquisa manejada pelo descobrimento (discozery-dri zer).

Conversamos um pouco mais sobre especulações e novas teorias científicas da área biológica, e o Lenzi passou a discorrer sobre dois achados científicos importantes. O primeiro fato tem a ver com a divisão da imunologia entre inata e adaptativa. Lenzi não gosta dessa divisão e prefere discriminar duas fases filogeticamente distintas na evolução ou filogenia do sistema imune: a pré-linfocitária e a pós-linfocitária. Como aparecimento dos peixes cartilaginosos com mandíbulas, os condrictes, surgiram os linfócitos B e T, que se caracterizam por possuírem receptores específicos [imunoglobulina e receptor $\mathrm{T}(\mathrm{TCR})$ ] que formam rearranjo gênico. Para que o rearranjo ocorra, é necessária a participação dos genes RAG 1 e RAG 2, os quais codificam componentes da $V(D) J$ recombinase $(V=$ variável; $\mathrm{D}=$ diversidade e $\mathrm{j}=$ joint ou junção), ou codificam fatores de transcrição ou outro tipos de proteínas que ativam a maquinaria da $\mathrm{V}(\mathrm{D}) \mathrm{J}$ recombinase. A parte fascinante desta história foi a descoberta de Oettinger e colaboradores, do grupo de D. Baltimore (Science, 248:1.517-1.522, 1990), os quais detectaram que os genes RAG em mamíferos, aves e anfíbios têm regiôes codificadoras sem íntrons e estão muito próximas umas das outras, caracterizando uma situação rara em genomas de vertebrados. Esses genes têm o aspecto de uma unidade carreada para o interior do genoma a partir de um organismo unicelular, como uma levedura ou uma bactéria, onde genes justapostos e sem intros são comuns. Esses autores concluíram que os RAGs foram parte de retrotransposons e tiveram a função de rearranjar o DNA em sua vida prévia. É possível que os ancestrais dos genes RAG tenham sido horizontalmente transferidos numa linhagem de metazoa, em 
algum ponto recente da evolução (peixes cartilaginosos?). Então, foram infecções virais que provocaram a virada do sistema pré-linfocitário para pós-linfocitário!!!

A história não termina aí: vale a pena destacar um segundo achado importante e interessante, observado há pouco tempo! Pesquisadores começaram a caracterizar as moléculas que participam na interação de espermatozóide com óvulo. Estudando espermatozóides de hamster, detectaram uma molécula dímera, cujo domínio extracelular da subunidade $\alpha$ apresenta uma região hidrofóbica de aproximadamente vinte aminoácidos que se assemelha a regiões fusogênicas de proteínas de fusão virais, as quais mediam a fusão de envelopes virais com as células que eles infectam. Isso significa que foi por meio de infecções por vírus que alguns animais, na evolução, adquiriram a capacidade de se reproduzir sexualmente pela fusão de duas células haplóides diferentes, isto é, de um espermatozóide com um óvulo. Evidências dessa ordem vão lançando hipóteses de como começou a reprodução sexuada com células germinais haplóides distintas.

Esses dois achados exemplificam a importância de transmissões horizontais no transcurso da filogenia, mostrando que nós somos resultado de um verdadeiro embaralhamento gênico entre seres distintos. Na realidade, somos uma salada de genes provenientes de diversos tipos de ancestrais! Uma verdadeira humilhação para os antropocentristas e os racistas! Os vírus parecem atuar como um dos principais cozinheiros da salada da evolução, a qual está essencialmente composta por bactérias e arquéias. A bricolagem gênica dos seres já fora imaginada pela mitologia grega: Prometeu, ao formar a criatura humana, misturou touro, burro e lebre ao limo, o qual servia de base para as qualidades dos diversos animais! Talvez da mistura com burro tenha surgido a burocracia! (ou burrocracia?).

Falando nisso, você conhece os livros da LynnMargulis? Há vários livros dela que não há como deixar de ler. São maravilhosos! Ela é uma bióloga, catedrática honorária do Departamento de Biologia da Universidade de Massachussets em Amherts, EUA, forte defensora da idéia da simbiose 
como um dos principais mecanismos propulsores da evolução. Segundo ela, a evolução se dá mais por interação contínua, coabitação e mútua dependência das distintas espécies do que por competição e sobrevivência dos mais aptos. Seu filho, Dorion Sagan (autor de Biosferas), é jornalista científico e facilita a divulgação de suas idéias. Escreve com a mãe alguns livros, facilitando a comunicação com o público. Ela é autora de The Origin of Eukarjotic Cells (1970) e Symbiosisin Cell Evolution. É co-autora com Karlene V. Schwartz de Cinco Reinos: guía ilustrada de los phyilla de la vida en la Tierra (1988). ComRené Fester editou Symbiosisas a Sourceof Evolutionary Imnovation: speciation andmor phogenesis (1991), e com seu filho Dorian publicou Microcosmos four billion years of evolution from our microbial ancestors (1986), Origins of Sex (1986), Danza Misteriosa (1991) e What is Life (1995), com prefácio de Niles Eldrege. A maioria deles comprei em Buenos Aires. Aliás, enquanto aqui no Brasil aumenta exponencialmente o número de farmácias, em Buenos Aires nascem livrarias! Os livros de Margulis são verdadeiros romances da vida, mostrando a dependência dos seres entre si. Demonstram que somos um agregado de bactérias e arquéias e thermoplasma ${ }^{46}$ anulando a concepção tradicional e antropocêntrica de parasitismo! Eu sempre digo ao Prof. Luis Rey para substituir, em seu excelente livro, a palavra 'parasitologia' por 'coabitologia'! Para concluir esta parte de nossa conversa, vou citar um trecho do epílogo do livro Queésla Vida, de Margulis e Dorian: "Homosapiens tiende a disipar calor y acelerar la organización. Como todas las demás formas de vida, nuestra estirpe no puede continuar expandiéndose indefinidamente. Ni podemos continuar destruyendo los seres de los que en última instancia dependemos. Tenemos que comenzar a escuchar al resto de la vida. Cuando se escucha sola, nuestra melodía en la ópera viviente es

\footnotetext{
${ }^{46}$ Bactérias: todos os procariotos que não são membros do domínio das arquéias.

Arquéias: o domínio filogenético de procariotos que consiste dos metanógenos, halófilos e hipertemófilos que vivem em condições extremas de temperatura e salinidade.
} 
repetitiva y persistente. Podemos creernos creativos y originales, pero en eso no estamos solos. Admitámoslo o no, somos sólo um tema en la orquestración de formas de vida. Con su glorioso pasado no humano y su incierto pero prometedor futuro, esta vida está ahora integrada, como siempre lo ha estado, en el resto de la sinfonía sensible de la vida. Ahora, como antes, la vida recibe su energia del Sol. Es un fenómeno no solo molecular, sino astronómico. La vida está abierta al universo y a sí misma. En la tradición de Charles Darwin, Samuel Butler, Vladimir Vernadskyy Erwin Schrödinger, podemos plantaernos con curiosidad la cuestión de qué es la vida, pero sólo podemos responder provisionalmentey con humildad, esperando, junto con quien nos lea, que la investigación continue" (Margulis, L. \& Sagan, D. Quées la Vida? Barcelona: Tusquets Editores, 1996).

Todos os exemplos que comentamos acima destacam a importância de superarmos as três pragas conceituais que ainda imperam na pesquisa biomédica atual: o antropocentrismo; a concepção militarista, que considera o sistema imune como teleologicamente destinado à defesa, com até mesmo células assassinas e matadoras!; e a linearidade. $\mathrm{O}$ estudo da evolução dos seres, com forte participação da biologia molecular evolutiva, e de sistemas complexos servirá como um agente terapêutico antagonista dessas três pragas, responsáveis por grande atraso no avanço do conhecimento biológico.

Ainda falamos bastante sobre tais livros e outros mais; saí de lá com referências diversas para me deliciar no mundo da leitura e ampliar o vôo da imaginação que um bom livro sempre desperta.

Nada como conversar com um cientista que, embora pesquise um mundo específico, está antenado com o movimento da ciência de seu tempo e é capaz de trazer infor mações recentes, discutir novos paradigmas e hipóteses que ainda se esboçam, mas sem dúvida instigam o espírito de quem ama investigar. A conversa ultrapassou em muito o horário do almoço, mas o alimento rico do espírito nem permitiu que eu me desse conta da fome do corpo, de tão interessante que foi a conversa. Tem sido um privilégio poder 
entrevistar pessoas como o Lenzi e os demais cientistas aqui apresentados, e espero novamente poder transmitir a você, leitor, o prazer e a riqueza desses momentos.

\section{Memórias do Início da Carreira em Salvador: Dr. Zilton e a modulação do granuloma}

Começamos a conversar sobre Dr. Zilton de Araújo Andrade, mestre do Lenzi (e de sua esposa, Dra. Jane, também pesquisadora), de quem fala com grande admiração e carinho. Contou-me sobre a importância de um trabalho do Dr. Zilton sobre a modulação do granuloma, o qual foi responsável pela entrada do Dr. Kenneth Warren, cientista que passou a dar uma grande contribuição neste campo, na área da esquistossomose. Lenzi conta que, na época, o Dr. Warren trabalhava na Case Western Reserve University em Cleveland, Ohio, EUA, e foi visitar o Dr. Zilton em Salvador, onde ficou um tempo fazendo estágio. Ele ficou atento à observação da modulação do granuloma, fenômeno já percebido e descrito pelo Dr. Zilton. Assim, montou diversos testes em que confirmou experimentalmente aquela observação. Trata-se de um trabalho clássico e importante de modulação que gerou e ainda gera muitos trabalhos na literatura científica mundial. Foi o Dr. Zilton quem introduziu o K. Warren no mundo da esquistossomose, área na qual ele acabou dando valiosa contribuição. Posteriormente, Dr. Warren assumiu, como influente diretor, os serviços de saúde da Fundação Rockefeller. Foi um dos homens mais inteligentes que conheci!

Como o Dr. Warren, o Dr. Zilton foi o iniciador de muitos outros cientistas que hoje trabalham em Manguinhos, dentre os quais o próprio Lenzi. Segundo Lenzi, ele foi o primeiro residente 'estrangeiro', de fora da Bahia, recebido no laboratório do Dr.Zilton Andrade. Durante o seu curso de medicina, Lenzi despertou para a área da radiologia. Foi conversar com 
um grande radiologista de Porto Alegre, Prof. Nelson Porto, que lhe recomendou dois caminhos possíveis para tornar-se um radiologista competente: a dermatologia ou a patologia. Lenzi, surpreso, logo the indagou: "Por que dermatologia?" "Porque as doenças se manifestam na pele e, se você entender a pele, vai entender clínica; porque a maioria das doenças tem manifestações cutâneas e um radiologista precisa entender a clínica geral para entender o paciente. É como entender o fora e o dentro. Já a patologia vai te dar uma base sólida das doenças, necessária para entender a radiologia [de fato, na época, a radiologia era uma patologia em preto e branco!]." Lenzi achou o caminho da patologia mais lógico, e decidiu então fazer um estágio no laboratório de um dos maiores patologistas de Porto Alegre, Dr. Luís Alberto Fagundes, formado no Massachusetts General Hospital em Boston, estabelecimento filiado à Universidade de Harvard. $\mathrm{Na}$ ocasião, o Dr. Fagundes organizava a Jornada Regional Sul de Patologia. Para o evento ele convidou um grande patologista, Dr. Castleman, responsável pelas famosas sessões anátomo-clínicas daquele hospital, regularmente divulgadas na revista Nerw England Journal of Medicine. E quem veio fazer a tradução das conferências do Prof. Castleman foi um patologista baiano chamado Zilton Andrade. Deixo então que o próprio Lenzi continue a nos contar a sua história.

Naquela época eu era um jovem estudante e fiquei responsável pela divulgação do evento, repassando as informações para os jornalistas, o que me possibilitou um contato diário com os conferencistas. Havia uma sessão diária de discussão de lâminas no laboratório do Dr. Fagundes, que era o presidente do evento, e um dia o Dr. Zilton foi convidado a dela participar. Eu o achei muito simpático, cativante, e depois fiquei impressionado quando ele traduziu o Castleman. Na realidade, fiquei mais impressionado com ele do que com o próprio conferencista. Aí cheguei para o Dr. Fagundes e lhe disse que queria encontrar um bom lugar para fazer a minha formação em patologia. Dr. Fagundes, fumando seu cachimbo, logo respondeu: "Para seguir a formação de patologia, você tem três lugares no Brasil: ou você vai 
com o Prof.Matosinho no Hospital dos Servidores Públicos em São Paulo, onde há um movimento muito grande de patologia cirúrgica de rotina, ou, se você quer uma formação mais acadêmica, recomendo dois outros serviços, um em Botucatu, com o Prof. Mario Rubens Montenegro, e outro na Bahia, com o Prof. Zilton de Araújo Andrade".

$\mathrm{Eu}$, sem titubear, escolhi ir para o Serviço do Prof. Zilton Andrade, que ficava no Hospital das Clínicas Edgard Santos (HPES) da Faculdade de Medicina da Universidade Federal da Bahia (UFBa), em Salvador. Falei então com a Jane, minha esposa, que estava grávida e fazia biologia (ingressou na medicina mais tarde, em Salvador). Ela, com sua maravilhosa intuição feminina e coragem, logo me apoiou. Então, eu e Jane juntamos os nossos badulaques e dissemos para as nossas famílias que iríamos para Salvador. Nossos parentes, estupefatos, exclamaram: "Que aventura vocês vão fazer!" Com o entusiasmo de uma aventura, pegamos um ônibus de Porto Alegre a São Paulo e dali para Salvador, pela Rio-Bahia. Naquele tempo, era 1969, a estrada entre o Rio e a Bahia acabara de ser construída. Ir para a Bahia, para o gaúcho, era o mesmo que ir para um outro país, diferente e distante! Quando, em São Paulo, entramos no ônibus da empresa São Geraldo, achamos o pessoal bastante estranho. Fomos andando e, quando chegamos no norte de Minas, naquela pobreza, o ônibus fez uma parada para comermos alguma coisa. Eu falei: "Jane, para onde nós estamos indo?" Que coisa, era um outro mundo! "O que vamos comer? Coisa horrível, tudo sujo, os banheiros imundos!" "O quê? Para onde estamos indo, tchê?" E o ônibus continuava indo, indo, e tinha uma baiana sentada em poltrona atrás da nossa que só tagarelava, sem parar, falando maravilhas de Salvador, que a Bahia era e tal e tal coisa. Mas naquela época Salvador não era tão bonita como hoje, era a Salvador dos açougues de carnes expostas e de ruas sujas! O ônibus foi entrando na periferia da cidade. Havia uma grande diferença em relação ao Sul. No Sul, ao se chegar em um grande centro, passava-se antes por cidades localizadas na sua vizinhança. No Nordeste daquela época era diferente: a estrada de repente desabava numa 
cidade. Então foi como se Salvador surgisse do nada! Salvador naquele tempo não tinha grandes avenidas perimetrais, nela se chegava pela periferia, caindo quase que direto na antiga rodoviária. Meio assustados, eu e a Jane nos instalamos num hotelzinho próximo à rodoviária. Lá, num quarto simples, ligamos o rádio para ouvir as estações locais. Ouviam-se músicas só cantadas e as propagandas apregoavam as belezas da cidade. E nós nos perguntávamos: onde está essa Bahia tão decantada pelos baianos? Mas logo veio a boa surpresa. No dia seguinte, criamos coragem e, ainda um pouco atônitos, fomos ao Hospital de Clínicas, para nos apresentarmos ao Prof. Zilton. Descemos até o Serviço de Patologia (tradicionalmente, os engenheiros de hospitais costumavam instalar os Serviços de Patologia perto das áreas de apoio, tipo lavanderias!). Como Dr. Zilton não se encontrava lá no momento, fomos recebidos por um médico residente em anatomia patológica, Dr. Antônio Teixeira, que nos acolheu com todo carinho e hospitalidade. Atualmente, ele é um pesquisador conceituado, trabalha muito em doença de Chagas e está na UnB. Na época, estava no segundo ano de residência. Passamos a conhecer outros componentes do Serviço de Patologia, principalmente Dr. Sérgio Santana, que nos acolheram da forma meiga, gentil, amável e cordial típica dos baianos, até que chegou o Dr. Zilton. A partir daí viramos baiúchos, isto é, misto de baiano e gaúcho, e fomos enredados pelo encanto daquela terra que nos deu amizade, alegria, exemplos de vida, conhecimentos de patologia e medicina, cultura brasileira e, acima de tudo, um filho maravilhoso, chamado Henry (está fazendo medicina em Porto Alegre).

Introduzi essa historinha só para contar como acabei fazendo minha residência médica em patologia, sob a orientação do Dr.Zilton, numa terra que parecia tão estranha e distante. Ao mesmo tempo que passei a cursar a residência, a Jane começou a se preparar para ingressar na medicina, um sonho antigo que ela acalentava. Esse sonho tornou-se real no ano seguinte, quando foi aprovada no vestibular de medicina. Foi um momento de muita felicidade para nós! A Jane, antes do vestibular, teve a sorte de aprender 
histotecnologia com uma histotecnologista de alta qualidade, chamada Zulmira Santana. Ficou então responsável pela organização de uma coleção de lâminas de patologia que foi distribuída para várias disciplinas de patologia de faculdades federais de medicina, acompanhando um livro de patologia publicado pela Fundação Kellog e escrito pelos professores Manoel Barreto Netto, Mario Rubens Montenegro, Thales de Brito e Zilton Andrade. Esse aprendizado que a Jane vivenciou antes da medicina, bastante distante no tempo, foi muito útil quando da instalação do laboratório de histotecnologia e do treinamento de pessoal técnico do atual Departamento de Patologia do IOC. Então, a Jane e eu vivenciamos, durante minha residência médica na Bahia, um ambiente extraordinário, cativante, altamente acadêmico e lúdico. Foi, sem dúvida nenhuma, um dos períodos mais lindos de nossa vida. Quando Maria Serena Palieri perguntou a Domenico de Masi, numa entrevista publicada em O Ócio Criatiro (Rio de Janeiro: GMT Editores, 2000), qual o continente que, em sua mente, mais se concilia de forma natural com o ócio criativo, ouviu dele, após completar uma volta pelo mundo, a seguinte opinião: "No Brasil. Pelas ruas do Pelourinho, no Jardim Botânico do Rio, nas igrejas de Ouro Preto, nas favelas de São Paulo ou de Salvador, nas ruas de Brasília e nas enseadas de Angra dos Reis. Em nenhum outro país do mundo a sensualidade, a oralidade, a alegria e a 'inclusividade' conseguem conviver numa síntese tão incandescente". $\mathrm{E}$, em outro trecho: "O caso que pode ser uma referência para a civilização do tempo livre certamente não é Seattle de Bill Gates, onde a corrida ao sucesso produz uma sociedade desequilibrada e infeliz, mas sim a Atenas de Péricles, onde o ócio criativo permitia equilíbrio e beleza. Sob este aspecto, a região da Bahia pode ensinar muito mais do que a região do Vêneto ou do Rio Grande do Sul". Portanto, na Bahia se aprende a diferença entre existir e viver!

Dr. Zilton é um mestre exemplar. Ele dizia assim: "Conhecimento não é propriedade". Ele comprava um livro e o livro era compartilhado com todos. Essa atitude eu e a Jane aprendemos com ele e fizemos questão de implantar em nosso departamento: passamos a rotulá-la de teoria dos vasos 
comunicantes, isto é, quando um aprende e passa os conhecimentos para os colegas, todos ganham em conhecimentos adicionais. É a simbiose no aprendizado! Frequientemente, logo que Dr. Zilton adquiria um livro, ele sumia, abocanhado pelos ávidos residentes (médicos que faziam a residência em patologia). E quando ele precisava do seu livro, tinha de ir à sala dos residentes, pedi-lo emprestado. Ele estava sempre disponível, de porta aberta, em contato permanente com os residentes. Irradiava sempre jovialidade! Eu e a Jane ficávamos impressionados com a forma como ele subia e descia as escadas, sempre com um sorriso, sempre positivo, sempre estimulando a todos. Eu, até emocionado, posso dizer que a Jane e eu tivemos um magnífico e extraordinário pai científico, que foi e sempre continua sendo um protótipo de como se deve vivenciar e fazer pesquisa. Ele ensinava a mim e à Jane, não com palavras, mas na própria vivência, que, para se fazer pesquisa com profundidade e qualidade, é importante dar um passo a cada dia. Não se corre na pesquisa, caminha-se. Hoje eu entendo esse ensinamento quando ando rápido com um carro em um túnel: a velocidade impede de ver a paisagem do caminho! Ele e a Dra. Sônia Gumes Andrade, que também é uma pessoa fantástica, compõem um casal que se amplifica, irradia uma grande energia, uma auréola de bondade, generosidade e conhecimento. A vida é feita de encontros, e encontrar o casal Zilton-Sônia foi, para mim e Jane, como encontrar uma pérola preciosa neste imenso mundo, a qual se carrega no colar feito de pedras de cada dia. Esta pedra está no centro do colar, é especial e brilha eternamente!

A Patologia do Hospital Edgard Santos constituía um meio acadêmico fascinante, estava sempre cheia de jovens, do quarto ano a residentes. Gabriel Grimaldi Filho (naquela época no $4^{\circ}$ ano do curso de medicina da UFBa) começou ali sua formação, vivia em coletividade, de acordo com seu princípio de tudo repartir. No Serviço de Patologia, naquele momento, ainda havia muito por fazer. Como eu entendia de marcenaria e o Gabriel também, decidimos fazer algumas melhorias. Para tal, construímos, ao lado da sala de autópsias, o primeiro moluscário, planejado pelo Gabriel. 
Estávamos na década de 70, bem no seu início, em torno de 70, 71. Era a época da contracultura, e o Gabriel era muito espontâneo, livre e despretensioso. Nas sessões científicas, fazia umas considerações interessantes, observações agudas, além de chamar atenção por seu jeitão meio exótico. Ainda em torno do Zilton, circulava também o sempre educado e aristocrata Dr. Bernardo Galvão Castro Filho, que mais tarde criou o Departamento de Imunologia no IOC. Assim, aqui na fundação, hoje estamos eu, a Jane, o Gabriel, todos egressos do grupo do Dr. Zilton. O Galvão, anos mais tarde, retornou para a Bahia para chefiar um laboratório voltado para pesquisas sobre HIV. Galvão foi um pioneiro, um dos pesquisadores, no Brasil, a perceber a relevância epidemiológica e médica do vírus do século!

Dr. Zilton foi muito importante também na formação de pessoas de fora do país. Influenciou, em esquistossomose, a formação de $\mathrm{K}$. War ren e Allen W. Cheever. Este, além de grande patologista, é uma figura humana extraordinária, que irradia bondade e ensina a arte de aliar simplicidade e sabedoria.

Um dia eu estava olhando, como residente $\mathrm{R} 2$, lâminas da rotina cirúrgica, quando Dr. Zilton, que estava ocupado numa reunião científica, pediu-me que atendesse dois jovens franceses que estavam prestando o serviço militar aqui no Brasil. Então, tive a honra de ser o primeiro a mostrar lâminas de esquistossomose para Dr. Jean-Alexis Grimaud e Dr. Radovan Borojevic, hoje na UFRJ. Atualmente, ambos são pesquisadores altamente conceituados, responsáveis pela produção de trabalhos marcantes sobre a patologia e patogenia da esquistossomose. Dr. Zilton teve uma importância muito grande no desenvolvimento científico de Grimaud, que chegou a ser o diretor do ex-Instituto Pasteur de Lyon e hoje trabalha em Paris.

A grande contribuição do Zilton na intelecção da patogenia do granuloma foi, sem dúvida nenhuma, a percepção da ocorrência do fenômeno da modulação. Depois, a partir dos trabalhos de $\mathrm{K}$. Warren, a imunologia passou a usar o granuloma esquistossomótico como modelo 
para estudo de mecanismos de regulação imune sobre esse tipo peculiar de reação inflamatória. Dr. Zilton intuiu a modulação ao observar que os granulomas em pacientes mais velhos eram menores do que em mais jovens. Essa foi realmente uma observação morfológica importante, que merece ser relatada pelo próprio autor. Mais de uma vez sugeri ao Dr. Zilton que escrevesse essa história com detalhes.

Anterior a tudo isso, deve-se destacar o convívio do Dr. Zilton com o Dr. Aluizio Prata, que era o chefe da Medicina Tropical do Hospital das Clínicas Edgard Santos. O primeiro trabalho do Dr. Zilton foi sobre tumor testicular, realizada em Saint Louis, Nova Orleans, sob a orientação de um renomado patologista norte-americano. Naquela época, as doenças infecciosas ainda não constituíam tema de estudo. Mas, em seu retorno, Dr. Prata, com sua, digamos, penetrante persuasão, induziu o jovem Zilton a se concentrar em doenças infecciosas e parasitárias, tão prevalentes na Bahia e em todo o país, alterando sua trajetória. O Dr Prata é uma pessoa que vale a pena entrevistar. Trata-se talvez do maior tropicalista médico da atualidade, e parece que bebeu a seiva da eterna juventude. Porta a alma de um aristocrata! Se eu fosse espírita e acreditasse em reencarnação, diria que no passado ele foi um grande cavalheiro, quiçá um rei poderoso, mas profundamente humano, que se casou com uma linda princesa chamada Marta!! Foi também ele quem convidou a mim e ao Galvão para, após a nossa residência em patologia, ingressarmos como jovens professores na UnB. Nós, Galvão e eu, fazíamos a parte da patologia nas sessões anátomoclínicas de seu serviço (Clínica de Medicina Tropical do HPES da UFBa). Acho que ele gostou da nossa atuação e nos convidou. Depois entendemos que a razão precípua da nossa ida para Brasília foi compor, na Faculdade de Medicina da Universidade de Brasília (UnB), uma equipe liderada pelo Dr. Zilton. Na UnB havia muita política. O Prata tinha sido da Marinha e o reitor da UnB também era militar. Então havia, por parte de alguns professores, um antagonismo contra ele. Era como se existissem dois partidos na Faculdade de Medicina: um pró-Prata e outro anti-Prata. Então 
eu e o Galvão, ingênuos ex-residentes, nos vimos entre uma saraivada de balas, atiradas dos dois lados. Agachados e entrincheirados atrás de microscópios e livros, erguíamos a bandeira branca da paz, e trabalhávamos como se nada estivesse acontecendo. Foi nossa primeira a grande escola sobre a vida e sociologia acadêmicas ou dos acadêmicos. Mas o Dr. Prata tinha muito personalidade, era muito conceituado (não se esqueçam de que pode ter sido um rei no passado!) e trabalhava para propiciar contextura e maturidade à jovem e adolescente Faculdade de Medicina. Eu e a Jane chegamos a presenciar, na casa do Prof. Prata, o momento em que ele convidou efetivamente o Dr. Zilton para a UnB. Mas foi a Dra. Sônia quem teve o bom senso de antever a instabilidade da UnB daquela época, fazendo com que o Dr. Zilton, mesmo insatisfeito com a Universidade da Bahia, lá permanecesse. Foi o término de um sonho passageiro, não só para o Dr. Prata, mas também para nós. Assim, Galvão e eu, longe do nosso mestre, tivemos de rapidamente saltar da adolescência científica para a fase de adulto jovem. Dr. Zilton continuou em Salvador, tornou-se professor titular, manteve sempre um bom grupo e, anos depois, organizou a pós-graduação em patologia e instalou a Fiocruz no Centro de Pesquisas Gonçalo Muniz, hoje pujante e moderno em decorrência da ação de um dos seus discípulos, Miter mayer Galvão dos Reis, que se revelou um extraordinário administrador, além de excelente pesquisador. Bernardo Galvão voltou para a Bahia, para fazer o mestrado, e eu fiquei mais um tempo na UnB. Depois, por uma série de razões, passei a trabalhar no recém-criado Hospital das Forças Armadas (HFA), inicialmente sob a chefia do Dr. Nestor Piva, vindo da Universidade Federal de Sergipe, um grande patologista e notável figura humana. O Serviço de Patologia do HFA estava muito bem equipado, e lá aprendi muita patologia, especialmente dermatopatologia, com o Dr. Piva. Com a saída dele para a UnB, assumi seu lugar na chefia, lá permanecendo até a Jane se formar médica pela UnB. Desgostoso com o desvirtuamento da filosofia inicial do HFA, a qual estava voltada para a criação de uma escola médica militar de alto padrão, assim que a Jane se formou pedi demissão, peguei o fundo de garantia (CLT) 
e voltei para Salvador a fim de fazer o mestrado em patologia humana. Terminado o mestrado, segui direto para o pós-doutorado - nos Estados Unidos o médico não precisa fazer o doutorado, pois já é medical doctor - em Harvard. Aí começou uma outra etapa que acabou, por uma série de intercorrências, nos levando para Manguinhos.

\section{A Vinda para Manguinhos: a descoberta de um curioso fenômeno biológico}

Em Harvard, fui fazer o pós-doutorado com o Dr. John David e a Jane, o mestrado com Dr. Thomas Weller (laureado com o Prêmio Nobel). Por coincidências da vida, lá estava também o Dr. Gabriel Grimaldi, fazendo estágio com Dra. Diana MacMahon-Pratt, descrevendo os primeiros monoclonais contra leishmania. Isso foi entre 1981 e 1983. Na véspera de voltar, a bolsa terminando, tínhamos uma criança pequena e a incerteza quanto a uma colocação no Brasil. Naquele momento, o Gabriel ofereceuse para falar com o Dr. José Rodrigues Coura, diretor do IOC, para que pudéssemos vir para Manguinhos. Foi um momento favorável, pois o Dr. Coura estava querendo organizar a Patologia do instituto e ainda não tinha conseguido um patologista para tal. Havia convidado o Prof. M. R. Montenegro, que não quis vir; tentou o Prof. M. Barreto Netto, que também negou o convite, pois todos já estavam instalados em seus serviços universitários. Então o Gabriel falou para o Dr. Coura e ele fez contato comigo e Jane. Escrevemos uma carta para ele, apresentando nossa filosofia de trabalho e ele nos mandou o convite para virmos para Manguinhos. Estávamos no segundo ano e ambos conseguimos renovações das bolsas por mais um ano, o que nos fez adiar a vinda para o IOC para o ano seguinte, mas sem garantia de que poderíamos ser absorvidos. Realmente, passado aquele ano, como Dr. Coura já não tinha mais a possibilidade de nos incluir no quadro de pessoal, viemos então como bolsistas do $\mathrm{CNPq}$, 
em 1984. Depois o Dr. Guilardo Martins Alves, então presidente da Fiocruz, me contratou como titular, assim que surgiu a primeira vaga. A Jane, após passar um tempo como pesquisadora do $\mathrm{CNPq}$, no Programa de Recomposição de Equipes de Pesquisa de Alto Nivel (Prepan), também foi contratada pela Fiocruz em 1987.

Quando chegamos em Manguinhos, o Departamento de Patologia não tinha nada. Segundo a Jane, os laboratórios do IOC daquela época pareciam quitandas! Logo ao chegarmos, fomos convidados pela Dra. Maria José von Paumgartten Deane para desenvolver um projeto conjunto sobre a infeccção por Tryppanosomacruzi em Didelphis marsupialis. A Jane preferiu se concentrar em esquistossomose e eu aceitei o convite da Dra. Maria, a qual era muito amiga do Dr. Gabriel Grimaldi. Como você está percebendo, o Gabriel tem muitos pontos de convergência com a nossa vida. Por exemplo: a sua ex-esposa, uma pessoa encantadora, chamada Pamela L. Moriearty, trabalhava com a Dra. Deane. Então foram eles que falaram com a Dra. Deane sobre mim e sobre a Jane. Assim que aceitei interagir, ela me chamou e disse: "Henrique, eu trabalho muito com gambás como modelo de estudo da doença de Chagas. Você não quer fazer a patologia para complementar os nossos estudos? Nós estamos infectando os gambás com diferentes cepas de tripanossomas e o Galvão já tem examinado uma parte do material. O problema é que eu não acho o parasita, a gente não sabe para onde ele vai dentro do hospedeiro gambá". Naquele tempo, não se encontravam gambás com a regularidade de hoje. Existia um gambatário velho, e os animais apresentavam raquitismo, síndrome de deficiência de cálcio. Então, após várias tentativas de dietas e rações, os animais passaram a se desenvolver normalmente. Como a Dra. Deane não tinha muitos gambás disponíveis, fazia experimentos aleatórios, infectando-os com cepas variadas, procurando responder a algumas questões que julgava importantes na biologia Trypanosomacruzi-hospedeiro reservatório, como o gambá. Passado um certo tempo, a pedido da Dra. Maria passei a orientar, com ela, a tese de mestrado de João Carlos Araújo Carreira, Histopatologiada Interașão Trypanosoma-Didelphis 
marsupialis. Obtivemos vários resultados interessantes, os quais foram difíceis de publicar devido a deficiências metodológicas derivadas da escassez de gambás. Era um tipo de investigação mais baconiana do que galileana. Íamos tateando, avaliando os resultados, nos deleitando com a sabedoria humana e científica irradiada pela grande mestra. Após essa digressão, vou voltar à história inicial. Decidi, então, pôr a mão na massa e iniciar a análise das lâminas anteriormente preparadas pelo Galvão. Examinei-as atentamente e também não consegui desvendar a 'habitação' do Trypanosoma cruzi nos gambás necropsiados por ele. Então, pensei: se o colega, competente patologista, não encontrou o parasita no material examinado, vou procurálo em locais não previamente explorados, onde ninguém teve a curiosidade de examinar! Então exteriorizei à Dra. Maria o meu desejo de necropsiar pessoalmente gambás infectados. Peguei o primeiro animal e realizei uma necropsia extensa, como costumo fazer em qualquer animal infectado com Trypanosoma cruzi, pois este protozoário vive nos mais diversos sítios do organismo, exigindo sempre uma verdadeira e trabalhosa 'pescaria' para encontrá-lo. Decidi examinar as glândulas do cheiro que conferem tanta popularidade a esse fascinante animal! Seccionei as duas glândulas, fiz um imprinte em lâminas e, após fixação em formalina Millonig de Carson, encaminhei as glândulas e os numerosos blocos para processamento histológico convencional. Antes de o material por mim processado ficar tecnicamente pronto, passei a examinar lâminas com material procedente de vários gambazinhos, recém-saídos da bolsa marsupial. Eles são um excelente modelo para trabalhos de imunologia, pois saem do útero para continuar se desenvolvendo na bolsa marsupial, num estágio equivalente a um feto humano de sete semanas. Observei então que a cepa $Y$ ia para o cérebro dos gambás jovens. E à medida que o gambá avançava em idade, instalava-se a barreira cerebral e os tripanossomas da referida cepa não mais se alojavam ali. Na tese do João aprofundamos este estudo com gambás de diferentes idades. Isto é, quando os animais adquiriam maturidade sexual e imunológica, a cepa Y não ia mais para o cérebro! Portanto, para esta 
cepa, a localização de seu hábitat no gambá estava parcialmente desvendada. Depois disso, comecei a examinar, com ansiedade científica (por que não dizer também emocional?) as primeiras lâminas do gambá que eu tinha necropsiado. Comecei a examiná-las na sala que Dr. Gilberto Teixeira nos havia gentilmente cedido quando a Jane e eu ingressamos no Departamento de Patologia. À medida que examinava cada lâmina negativa, minha ansiedade aumentava, aumentava, deixando-me quase tenso! Seguia a numeração das lâminas de acordo com protocolo usado na necropsia. Lá, quase nas últimas lâminas, passei a examinar as, para mim, desconhecidas glândulas do cheiro. De repente, passei a ver uma quantidade impressionante de parasitas! Saí apressado da sala, peguei o telefone e imediatamente liguei para a Dra. Maria! Na minha memória, deviam ser umas quatro ou cinco horas da tarde. "Dra. Maria, exclamei ao telefone, adivinhe onde o parasita habita o gambá?" Não esperei pela resposta e continuei exclamando! "Achei o bichinho e parece que ele tem uma tendência homossexual, pois vive nas glândulas do cheiro, perto do ânus!" Ela, também ansiosa, pediu: "Traga as lâminas aqui para olhá-las no microscópio". Peguei a caixa com as lâminas e saí literalmente correndo, como se estivesse fugindo de um leão, e cheguei esbaforido na sua sala, que ficava no Departamento de Protozoologia, no segundo andar do prédio Carlos Chagas! Ela, àquela altura, mais ansiosa do que eu, botou uma das lâminas no microscópio e exclamou: "Pá, que coisa fantástica!" Foi um dia cientificamente feliz para ambos!

Naquela época, eu e a Jane estávamos dando o curso de patologia geral, que fazia parte do curso básico do IOC, o qual durava um mês inteiro e nos ocupava integralmente. Antes, quem ministrava esse curso era o Prof. Zilton. Então, pela primeira vez, o referido curso foi assumido pelo Departamento de Patologia do IOC ou, mais precisamente, por mim e pela Jane. Dra. Maria estava ansiosa para publicar os novos achados, pois, de fato, tratava-se de um fenômeno ímpar na biologia dos tripanossomas, pois as formas parasitárias na glândula eram predominantemente epimastigotas e não amastigotas, reproduzindo aspectos observados nos 
triatomídeos, ou hospedeiros invertebrados. Ficava demonstrado, então, que no organismo do gambá o protozoário podia exibir dois ciclos em paralelo: o que se expressa no inseto vetor, o barbeiro, e o que se expressa no homem ou em outros hospedeiros vertebrados. Eu disse: "Dra. Maria, não tenho tempo agora, estou inteiramente absorvido pelas aulas do curso e só poderei examinar com profundidade o material e escrever o artigo após o termino do curso". Naquela época, Dra. Deane recebeu a visita do seu amigo, Dr. Victor Nussenzweig, e de um outro tropicalista conceituado da Universidade de Londres (esqueci o seu nome), a quem ela mostrou o material. Ambos o acharam muito interessante, confirmaram que se tratava de fato de um fenômeno biológico fascinante, e concordaram que poderia ser divulgado em uma revista científica de grande impacto. Devido à premência em publicar os dados, Dra. Maria se prontificou a escrever o trabalho, antes que o curso de patologia acabasse. E me pediu para ficar como autora, com o que concordei, considerando seu alto conceito internacional como parasitologista. Sugeri, naquela oportunidade, mesmo que isso me custasse a autoria, que a Dra. Ana Maria Jansen fosse também incluída como co-autora. Embora a Ana não tivesse participado diretamente do trabalho, ela era responsável pelo gambatário e tinha contribuído com entusiasmo para o aprimoramento da discussão, trazendo reflexões interessantes.

Mandamos a comunicação para o Nature, e a resposta veio rapidamente - pena a Dra. Deane não estar viva para lhe contar esta história. A secretária do Nature nem se dignou a enviá-lo para os revisores, dizendo, em poucas linhas, que o fato não se adequava à publicação e deveria ser submetido a revistas da área ou especializadas. Ficamos muito frustrados e tristes, fato muito humano, pois achamos que a importância do conteúdo não foi percebida pela secretária do Nature, que provavelmente ficava mais impressionada com artigos vindos do Primeiro Mundo, repletos de metodologias mais complicadas, chamadas de metodologias de ponta, como se a ciência tivesse cabeça e cauda. Deve ter pensado: "Que relevância tem 
um artiguinho brasileiro sobre um tal de Trypanosoma cruzi, num bicho fedorento como o gambá?" Além do mais, em nosso trabalho, os dados eram mostrados em lâminas coradas pelo Giemsa e/ou hematoxilina e eosina! (Que falta de metodologia sofisticada! É muita pretensão querer isso publicar em tão expressiva revista científica!) Dra. Maria ficou tão indignada que colou a folha com a resposta do Nature na parede atrás dela, em seu gabinete de trabalho. E a folha lá ficou até sua morte, como um símbolo de indignação! Então, ela disse: "Você quer saber de uma coisa? Vamos publicar na revista da casa, nós não podemos perder tempo, é um dado muito original". Mandamos então para a revista Memórias do Instituto Oswaldo Cruz, o editor priorizou e o primeiro trabalho sobre esse interessante evento da natureza foi rapidamente publicado (mas não do Naturel). Depois nós começamos a aprofundar a análise sobre a interação do Trypanosoma ơvzi com a glândula anal do gambá e o segundo trabalho sobre o assunto saiu em um número especial sobre doença de Chagas, organizado pelo Dr. José R. Coura, novamente na Memórias. Com o tempo, outros estudos passaram a ser feitos, pois achávamos que a natureza nos tinha fornecido um modelo para desvendar as condições nutritivas ideais para o cultivo de epimastigotas. Para tal, precisávamos caracterizar a composição bioquímica do conteúdo glandular. Mas, por falta de bioquímicos interessados no assunto, esse objetivo nunca foi alcançado!

Nos gambás inoculados experimentalmente pela equipe da Dra. Maria Deane, encontramos parasitismo intraglandular apenas com cepas de Trypanosomacruzi de gambá, a Gn e a G49. Noutras cepas, os parasitas não iam para a glândula do gambá. Os animais que tinham parasitas epimastigotas na glândula apresentavam também, concomitantemente, número variado de ninhos de amastigotas em vários locais, principalmente em tecido muscular. Esse assunto foi exaustivamente explorado na tese de mestrado de João Carreira, e posteriormente publicado. O fato de cepas isoladas de gambá irem para a glândula enquanto cepas isoladas de humanos não demostram esse tropismo sugere um processo de adaptação coevolutiva 
entre cepas de Trypanosoma cruzi triatomídeos e gambás que coabitam ecótipos especiais. No início todos nós ficamos preocupados com a possibilidade de estarmos lidando com um evento de laboratório. Todavia, assim que a comunidade científica foi se inteirando do assunto, o parasitismo intraglandular em gambás passou a ser identificado in natura. Por meio de microscopia por varredura, demonstramos que a glândulaé cheia de fossetas ou pequenas reentrâncias, onde numerosos tripanossomas ficam alojados sem desenvolver alterações patológicas intraglandulares. Isso sugere que a glândula funciona como um sítio privilegiado para o Trypanosoma cruzi, favorecendo também o hospedeiro. Isto é, o parasita prolifera abundantemente e o gambá nada sofre, caracterizando mais um belíssimo exemplo de coabitação entre seres filogeneticamente distintos.

$\mathrm{Na}$ ausência da Dra. Deane, que era uma pessoa muito integradora, cada um de seus discípulos e colaboradores seguiu seus próprios caminhos. $\mathrm{Na}$ biologia não há espaços vazios, e indivíduos únicos substituem indivíduos únicos! Mas, empregando o aforismo de George Orwell, que diz que entre todas as obras únicas de arte algumas são mais únicas, podemos também dizer que, entre todas as pessoas únicas do IOC, Dra. Maria foi mais única. Oindivíduo Maria P. Deane desapareceu para sempre, mas persistem, usando uma expressão de Richard Dawkins, seus 'memes'. Aqui convém lembrar algumas singelas lições que ela nos transmitia na vivência, as quais são importantes para os jovens pesquisadores da atual época da velocidade, que não tiveram a sorte de conhecê-la. Ela era uma pessoa muito criativa, pensante, profundamente crítica e contestadora. Enfatizava sempre que a pesquisa tem de ser lúdica, não uma coisa mercantilista; questionava a corrida aos financiamentos, que sufoca o pesquisador com a exigência de relatórios e mais relatórios, transformando os pesquisadores mais experientes em administradores ou gerenciadores de projetos! Como o Dr. Zilton Andrade, reforçava a idéia da importância de, na pesquisa, dar um passo a cada dia, com persistência e profundidade, não se deixando esmagar pela ciência da moda e nem ser dominado cientificamente pelo colonialismo dos países 
chamados centrais. Ela tinha também um espírito humorístico, quase inglês, e uma simplicidade cativante, própria dos sábios. Queixava-se muito do excesso de siglas da ciência. Dizia que um dia ainda daria uma conferência em Caxambu, no Congresso Anual de Doença de Chagas, sobre o DM, que foi infectado com TC, da cepa GN ou G49, desenvolveu uma ICP, e os níveis de $\mathrm{P}$ e $\mathrm{K}$ aumentaram MMM até o animal fazer UUU e cair RRR no chão! (Essa pequena história foi inventada por mim, apenas procurando reproduzir um de seus desejos não realizados!) Com isso aprendi que, às vezes, por trás de um 'sábio' pesquisador que fala difícil com siglas indecifráveis, reside um vaidoso ignorante, disfarçado de sábio!

Gostaria de terminar esta conversa citando o parágrafo final do interessante livro O Rato, a Mosca e o Homem, de François Jacob: "Somos uma temível mistura de ácidos nucléicos e lembranças, de desejos e de proteínas. O século que termina ocupou-se muito de ácidos nucléicos e de proteínas. O seguinte vai concentrar-se sobre lembranças e desejos. Saberá ele resolver essas questões?" 


\section{Henrique Leonel Lenzi ${ }^{47}$}

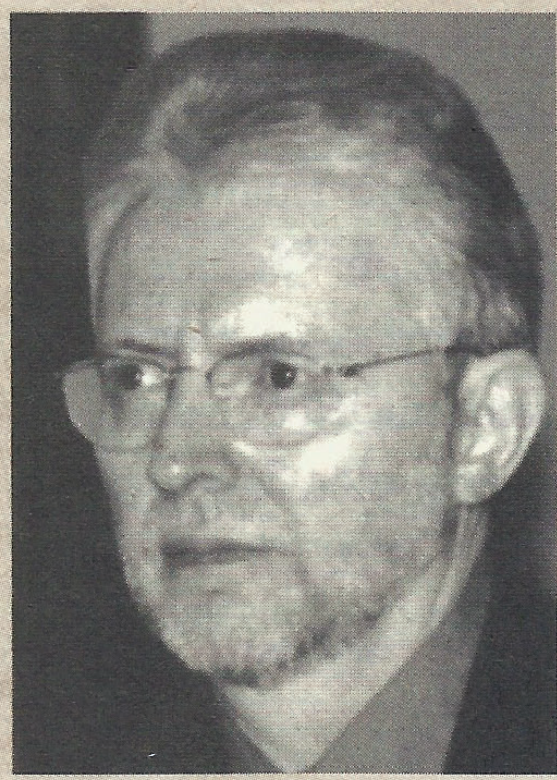

Dr. Henrique Lenzi nasceu na cidade de Paraí, Rio Grande do Sul, em 26 de junho de 1943. Formouse médico em 1969 pela Fundação Faculdade Federal de Ciências Médicas, em Porto Alegre. Fez residência médica no Hospital das Clínicas Edgard Santos, da Faculdade de Medicina da UFBa, em Salvador. Logo em seguida ingressou na Faculdade de Ciências Médicas da UnB, como professor. De 1973 a 1977 foi médico patologista do Hospital das Forças Armadas e do Hospital Presidente Médici, ambos em Brasília. Em 1980 concluiu o mestrado em patologia humana, pela Faculdade de Medicina da Ufba. De 1981 a 1983 foi research fellow na área de imunopatologia na Harvard Medical School, em Massachussets, EUA. Em 1991, doutorou-se em patologia geral pela UFMG. Em 1992, fez o pós-doutorado no Instituto Pasteur, em Lyon, França. Em 1984, tornou-se chefe do Departamento de Patologia do $10 \mathrm{C}$, cargo que exerce até hoje. Em 1986 foi vice-diretor do IOC, e de 1986 a 1989 foi superintendente de Informação Científica da Fiocruz, da qual foi também vice-presidente de Pesquisa entre 1990 e 1991. Além de pesquisador, tem sido professor em várias universidades brasileiras, em cursos de graduação e pós-graduação. Tem contribuído para a formação de novos pesquisadores, orientando diversas teses de mestrado e doutorado, assim como participado de

\footnotetext{
${ }^{47}$ Extraído do currículo breve cedido pelo pesquisador.
} 
comissões examinadoras de teses e organizado congressos nacionais e internacionais. É consultor de diversas agências e revistas científicas, membro de comissões científicas e responsável por projetos de pesquisa financiados por diferentes agências. Publicou mais de 250 resumos em congressos e cerca de setenta trabalhos em revistas nacionais e internacionais. 